\title{
Sprawozdanie
}

\section{Debata realizowana w ramach „Czwartków na Brukselskiej” nt: Znaczenie reprezentatywności związkowej dla funkcjonowania Dialogu Partnerów Społecznych, Warszawa, 3 marca 2011 r.}

Pracodawcy Rzeczypospolitej Polskiej (wcześniej Konfederacja Pracodawców Polskich) jest jedną z największych i najstarszych organizacji pracodawców w Polsce. Powstała w listopadzie 1989 r. i reprezentuje ponad 7000 firm. Przedsiębiorstwa zrzeszone w Pracodawcach RP zatrudniają ok. 3 mln pracowników. Zdecydowana większość z nich - $85 \%$ - to firmy prywatne. Organizacja jest aktywnym uczestnikiem dialogu społecznego w ramach obrad komisji sejmowych i komisji senackich. Uczestniczy w pracach decyzyjnych i doradczych gremiów różnych szczebli administracji państwowej oraz podejmuje inicjatywy i dyskusje na rzecz przedsiębiorczości, innowacyjności, wykorzystania nauki dla potrzeb gospodarki, a także w obszarze stanowienia prawa. W ramach tych idei organizowane są debaty zwane „ Czwartkami na Brukselskiej”. W dniu 3 marca 2011 r. dyskutowano nad znaczeniem reprezentatywności związkowej dla funkcjonowania dialogu partnerów społecznych.

Debatę rozpoczęto od przedstawienia jej programu. Poinformowano, że w pierwszej jej części przewidziane są wystąpienia Wiceprezydent Pracodawców Rzeczypospolitej Polskiej A. Kostrz-Kosteckiej oraz Doradcy Prezydenta Pracodawców Rzeczypospolitej adiunkta w Katedrze Prawa Pracy na Wydziale Prawa i Administracji Uniwersytetu Kardynała Stefana Wyszyńskiego w Warszawie, dr M. Gładoch. W drugiej części debaty do zabrania głosu zostali zaproszeni: Prof. dr hab. J. Wratny reprezentujący Instytut Pracy i Spraw Socjalnych oraz Instytut Nauk Prawnych PAN, T. Kuydynowicz - przedstawiciel Związku Pracodawców Polska Miedź, M. Szkałuba Wiceprezes Zarządu Polskiego Górnictwa Naftowego i Gazownictwa S.A. ds. Handlu, A. Węglarz - Przewodniczący Zarządu Związku Pracodawców Przemysłu Hutniczego oraz S. Adamczyk - Ekspert NSZZ „Solidarność”. W trzeciej części debaty przewidziano dyskusję z uczestnikami spotkania w ramach „Czwartków na Brukselskiej” oraz podsumowanie debaty. Na moderatora debaty wyznaczono dr M. Gładoch. 
Wiceprezydent Pracodawców Rzeczypospolitej Polskiej A. Kostrz-Kostecka rozpoczynając debatę przypomniała historię pluralizmu związkowego i zauważyła, że obecnie uzwiązkowienie w Polsce spada. Podkreśliła, że reprezentatywność związków zawodowych ma istotne znaczenie, ponieważ im więcej podmiotów związkowych przystępuje do rozmów tym trudniej jest wypracować wspólne stanowisko i osiągnąć konsensus. Często dochodzi do sytuacji gdy rozsądny dialog blokują nowo tworzone organizacje związkowe, które nie są zainteresowane prowadzeniem rozmów i bezkompromisowo dążą do obranego celu. Pani Wiceprezydent uznała, że obowiązujące regulacje prawne dotyczące reprezentatywności związkowej są niewystarczające i powinny zostać podjęte prace nad nowelizacją przepisów. Za istotny krok w tej dziedzinie uznała dzisiejszą debatę.

Dr M. Gładoch zaprezentowała znaczenie pojęcia reprezentatywności przytaczając m. in. Definicje M. Pliszkiewicza i M. Seweryńskiego, którzy prezentują pogląd, że reprezentatywność związku zawodowego lub organizacji pracodawców oznacza ich szczególną zdolność do występowania w określonych sprawach, w zbiorowych stosunkach pracy, a w szczególności $\mathrm{w}$ charakterze strony, w układach i porozumieniach zbiorowych oraz sporach zbiorowych. W swoim wystąpieniu dr M. Gładoch scharakteryzowała także uprawnienia organizacji związkowej i przejawy jej reprezentatywności w zakładzie pracy. Zaprezentowała stan prawny obowiązujący w Polsce oraz w wybranych krajach Unii Europejskiej. Uznała, że należy na nowo zdefiniować zasady funkcjonowania związków zawodowych, a głównym obszarem wymagającym regulacji jest zmiana przepisów dotyczących reprezentatywności związku zawodowego. Na świecie obowiązują różne jej kryteria: liczbowe, nominacyjne czy też desygnacyjne. W polskim prawie obowiązuje wyłącznie kryterium liczbowe, co często prowadzi do nieporozumień oraz znacząco wpływa na obniżenie jakości dialogu.

Prof. dr hab. J. Wratny poparł tezę o zaostrzeniu kryterium reprezentatywności i nadmiernym pluralizmie związkowym. Przywołał przykład PKP Cargo gdzie funkcjonuje rekordowa liczba 283 związków. Taka ilość związków zawodowych działających u pracodawcy rodzi kilka znaczących problemów, m. in. zmniejsza skuteczność działania organizacji związkowych, przedłuża procesy decyzyjne, powoduje gorsze traktowanie przez pracodawców i wpływa na wzrost kosztów po stronie pracodawcy, który dzięki ich liczbie może nimi w sposób stosunkowo łatwy manipulować lub je 
ignorować. Remedium na rozwiązanie tej sytuacji miało być ustanowienie kryterium reprezentatywności związków zawodowych. Jesteśmy na dobrej drodze ku temu, lecz procedury wybierania reprezentatywnych związków ciągle są skomplikowane. Przepisy wciąż umożliwiają tworzenie wielu takich organizacji. Pojawiły się różne propozycje zaostrzenia obecnych kryteriów reprezentatywności, tj. Podniesienie liczby progu, od którego możliwe jest utworzenie związku zawodowego w zakładzie pracy, dopuszczenie do reprezentatywności łączonej - kilka związków musiałoby przekroczyć pewien próg ilościowy i wyłaniałoby pośród siebie przedstawicieli, którzy negocjowaliby z pracodawcą. Inna koncepcja to wyłonienie reprezentatywnego związku zawodowego w drodze tajnego głosowania, w którym ten, kto uzyska największą ilość głosów, miał by mandat do rozmów z pracodawcą.

S. Adamczyk zauważył, że wyraźne preferowanie jednej organizacji związkowej może prowadzić do skrajności i kreowania żądań z jednej strony nie do przyjęcia przez pracodawcę a z drugiej daleko wykraczających poza oczekiwania pozostałych organizacji związkowych. Przytoczył przykład z Kopalni Węgla Kamiennego Budryk, gdzie niewielki i mało znaczący związek doprowadził do sporu zbiorowego. S. Adamczyk uznał, że należy się zastanowić nad umocnieniem wspólnej reprezentacji związków zawodowych, która spowoduje rozwój poszczególnych organizacji i da możliwość szerokiego reprezentowania pracowników. Nie zgodził się z tezą wiceprezydent Pracodawców Rzeczypospolitej Polskiej, A. Kostrz-Kosteckiej, która stwierdziła, że wspólna reprezentacja związkowa nie ograniczy rozproszenia związkowego i zauważył, że podobny układ funkcjonuje już w grupie Żywiec i doskonale się sprawdza.

A. Węglarz zaprezentował funkcjonowanie związków zawodowych w swoim zakładzie. Opracowanie wspólnego stanowiska odbywa się podczas spotkania tzw. zespołu roboczego, w skład którego wchodzi kilkunastu związkowców. Później to wspólnie wypracowane stanowisko przedstawiane jest w tzw. zespole centralnym. Zauważył jednak, że wciąż jest to jak siedzenie na bombie, ponieważ na zespole centralnym nawet najmniejszy związek może zgłosić swoiste liberum veto i zablokować wejście w życie wypracowywanych dokumentów bądź zmian. Przytoczył przykład Huty Katowice, gdzie po uzgodnieniu z trzema największymi związkami punktów porozumienia, niewielki związek zniweczył szanse na wejście w życie wypracowywanego dokumentu. A. Węglarz postulował, aby reprezentatywna była ta 
organizacja, która zrzesza odpowiedni procent załogi lub ta, która jest najliczniejsza. Uznał, że nie budzi uwag możliwość działania w zakładzie wielu związków, jednak to ostatecznie tylko z jednym pracodawca powinien prowadzić rozmowy.

A. Wystrzykowski zauważył, że także zbyt wysoki próg procentowy może rodzić kłopoty. Jeżeli przyjmiemy, że reprezentatywna będzie ta organizacja, do której należy np. 25 \% załogi, to w PGNiG takiej organizacji nie będzie, bowiem najliczniejsza z nich skupia 20 \% załogi. Dodatkowo ustawodawca nie przewidział sytuacji, gdy firma swoją centralę ma, jak PGNiG w Warszawie a pozostałe oddziały są rozrzucone po całym kraju. Oczywistym jest bowiem, że reprezentant związkowy ze Szczecina nie będzie zainteresowany problemami organizacji z południa Polski.

Z kolei T. Kuydynowicz zauważył, że w kontaktach pomiędzy stronami dialogu społecznego potrzebna jest duża doza racjonalizmu aby uniknąć licytowania się związków zawodowych na populistyczne i niemożliwe do spełnienia żądania w stosunku do pracodawców. Uznał, że należy doprecyzować pojęcie kompetencji związków zawodowych a dopiero później podjąć prace nad kryteriami reprezentatywności. Dodał jednak, że jeżeli chodzi o reprezentatywność, dobrym pomysłem może być koalicja związków zawodowych lub prowadzenie rozmów ze związkiem, który ma największe poparcie załogi.

Po wystąpieniu referentów dr M. Gładaoch zaprosiła uczestników spotkania do dyskusji zauważając jednocześnie, że być może dzisiejszy stan prawny najbardziej negatywnie wpływa na sytuację pracowników i pracodawców. W Polsce, bowiem wszczyna spór zbiorowy każdy nawet związek zawodowy nie mający zdolności układowej.

Głos w dyskusji zabrał reprezentant Związku Zawodowego Marynarzy NSZZ „Solidarność". Wyraził on ubolewanie, że nawet reprezentatywność nie daje gwarancji, że prowadzony dialog zakończy się sukcesem. Zauważył jednocześnie, że w obecnej chwili największym problemem jest likwidacja największych zakładów pracy i brak należytych warunków dla funkcjonowania związków zawodowych w prywatnych zakładach pracy. Powszechną praktyką jest zwalnianie pracowników, którzy choćby planują wstąpienie do związków. Rząd powinien dawać przykład jak prowadzić dobry dialog. Tymczasem od 3 lat nie wywiązuje się on należycie ze swoich funkcji i dąży do dalszej likwidacji dużych państwowych zakładów pracy. Uniemożliwio- 
no dodatkowo związkowcom wchodzenie do rad nadzorczych spółek Skarbu Państwa.

Głos w dyskusji zabrał także J. Śniadecki, Przewodniczący Związku Energetyków, który zaznaczył, że konieczne jest podjęcie prac nad nową kodyfikacją kodeksu pracy, tak aby przepisy nadążały za dynamiką rozwoju gospodarczego i społecznego. Zaskakującym jest fakt, że organizacje związkowe potrafią jednoczyć się w strukturach międzynarodowych a nie potrafią zrobić tego na szczeblu krajowym.

Opinię o osłabieniu i rozdrobnieniu związków zawodowych oraz regulacji reprezentatywności związkowej wyraziła także przedstawicielka Związku Zawodowego Poczta Polska. Uznała, że należało by skupić się na doskonaleniu prawa już funkcjonującego i wprowadzić zmiany do ustawy o związkach zawodowych a także podnieść próg możliwości tworzenia związków zawodowych.

Reprezentant Związku Zawodowego Kierowców uznał, że gorszy od mnogości związków jest ich brak. Pracodawcy zwalczają związki zawodowe. Należały, by zatem zrobić swoisty rachunek sumienia. Organizacje zrzeszające pracodawców powinny zwracać uwagę czy w ich strukturach nie ma firm, które tylko w czasie debat podobnych do dzisiejszej są skłonne do dialogu i fikcyjne akceptują funkcjonowanie związków zawodowych podczas, gdy w codziennej praktyce utrudniają nawet założenie związku zawodowego w ich zakładzie.

Głos zabrał także J. Czyż, Członek Polskiego Związku Emerytów i Rencistów, który wyraził przekonanie, że w mediach pomijana jest działalność organizacji związkowych. Instytucje publiczne i społeczeństwo nie są informowane o ich dokonaniach. Przypomniał, że ideą dialogu jest umiejętność ustępowania i wyrzekanie się osiągania prywatnych korzyści i celów.

$\mathrm{Na}$ zakończenie uczestnicy wspólnie uznali, że należy prowadzić dyskusje na temat reprezentatywności związków zawodowych, zbiorowych stosunków pracy i rozwiązywania sporów zbiorowych pracy. Powinniśmy jasno określać cele i poprzez dialog oparty na wzajemnym zrozumieniu dążyć do ich osiągnięcia. Dr M. Gładoch zaprosiła do prowadzenia rozmów i spotkań ekspertów, nawet nieformalnych, które jednak przyczyniłyby się do poprawy obecnej sytuacji i poprawy dialogu wśród partnerów społecznych.

Karina Całka-Lajnert (Uniwersytet Śląski) 